\title{
Effect of Body Condition Score on Milk Production, Milk Composition and Reproductive Performance of Lactating Murrah Buffaloes
}

\author{
M. Patel ${ }^{1}$, G.P. Lakhani ${ }^{1}$, S. Ghosh ${ }^{2}$, S. Nayak ${ }^{3}$, B. Roy ${ }^{1}$, R.P.S. Baghel ${ }^{4}$ and A. Jain ${ }^{1}$ \\ ${ }^{1}$ Department of Livestock Production Management, ${ }^{3}$ Department of Animal Nutrition, \\ College of Veterinary Science \& Animal Husbandry, Nanaji Deshmukh Veterinary Science \\ University, Jabalpur-482001, Madhya Pradesh, India \\ ${ }^{2}$ Nanaji Deshmukh Veterinary Science University, Jabalpur-482001, Madhya Pradesh, India \\ ${ }^{4}$ College of Veterinary Science \& Animal Husbandry, Nanaji Deshmukh Veterinary Science \\ University, Jabalpur-482001, Madhya Pradesh, India \\ *Corresponding author
}

\begin{abstract}
Keywords
Murrah buffaloes, Body condition score, Milk production, Milk composition,

Reproductive performance

Article Info

Accepted:

10 October 2018

Available Online:

10 November 2018 performance of lactating Murrah buffaloes. The Murrah buffaloes were distributed into three different groups with six animals in each group based on their pre-calving BCS (15 days before expected date of calving) namely G1 (2.50 - 3.00), G2 (3.25 - 3.75) and G3 (4.00 and above). BCS, daily milk yield up to 12 weeks of lactation, milk components (fat, protein, lactose, total solids and Solid Not Fat), Post-Partum estrus, service period, first service conception rate and numbers of service per conception were studied. The result of the present study indicated that there was decrease in BCS after calving in all the groups. G3 group animals produced highest total milk than G1 and G2 group animals, however the difference was not significant The G3 group animals attained their peak yield earlier compared to G2 and G1 group of animals and highest predicted lactation milk yeild. The increase in body condition score was accompanied by a significant increase in the content of fat, protein, lactose and total solid in the milk. The animals of G2 group had shorter postpartum estrus period, fewer services per conception, higher first service conception rate and shorter service period than G1 and G3 group. Thus in the present study, it was observed that BCS subsequently related to the production and fertility status of an animal.
\end{abstract}

\section{A B S T R A C T}

A total of 18 Murrah buffaloes of $1^{\text {st }}$ to $3^{\text {rd }}$ parity were selected to study the effect of Body Condition Score (BCS) in milk production, milk composition and reproductive

\section{Introduction}

The body condition score (BCS) system is a subjective scoring method of evaluating the energy reserves of dairy animals which provides a better understanding of biological relationship between body fat, milk production and reproduction that helps in adopting the optimum managemental practices to derive maximum production and maintain better health status. It is based on evaluation of the outer appearance of the animal that interacts 
with its body fat reserves and therefore is directly influenced by energy balance. It gives an immediate appraisal of the body state of the animal and is readily incorporated in operational decision making (Gransworthy, 1988). It has been considered an effective tool in monitoring the energy intake of cows and herds (Jeffrey and James, 1989). In order, to asses changes in body reserves as a consequence of negative energy balance BCS recording has been recommended (Berry et al., 2003). The body condition is usually judged through a 5-point scale, with 1 equivalent to an extremely lean cow, while 5 to a cow having excessive fat reserves (Peters and Ball, 1987).

The mobilization of body energy reserves is the major capability of the dairy cow and buffalo. The mobilization of reserves is indispensable for maintaining high milk yield following parturition. The dairy animals are normally in negative energy status at the start of lactation (Nielsen, 1999). The change in BCS in the first few weeks of lactation point towards the level of metabolic load as the shortfall of energy to milk production is considered to be met through mobilizing body reserves (Pryce and Løvendahl, 1999). Since energy intake does not maintain speed with continuously increasing milk yield, energy shortfall in early lactation enhances, creating a competitive conditions among milk yield, fertility and health status of the animal as all these traits are interlinked with energy.

India is the native tract for the best buffalo breeds of the world. In order to derive the maximum potential from native buffaloes and for their better management, there is a need to study the effect of BCS on milk production and its composition, reproduction in the subtropical environment of India with local dairy buffaloes under the existing management practices. Therefore, the present work has been carried out to assess the effect of BCS in milk production, milk composition and reproductive performance of lactating Murrah buffaloes under subtropical conditions of India.

\section{Materials and Methods}

\section{Animals and feeding}

A total of 18 Murrah buffaloes of $1^{\text {st }}$ to $3^{\text {rd }}$ parity were selected for the study at Livestock Farm, Adhartal, College of Veterinary Science and A.H., Nanaji Deshmukh Veterinary Science University, Jabalpur (Madhya Pradesh, India). The experimental animals were fed according to their body weight and production. Buffaloes were maintained in intensive system. Half of the total required quantity of feed offered daily at morning 5.30 am and rest of amount offered in the afternoon $3.00 \mathrm{pm}$. The water was kept available to animals round the clock.

\section{Grouping of animals}

Eighteen Murrah buffaloes were distributed into three different groups based on their precalving BCS (15 days before expected date of calving) namely G1, G2 and G3 with six animals in each group.

\section{Data recorded}

\section{Milk yield}

Daily milk yield up to 12 weeks of lactation was measured every day both morning and evening. Peak milk yield was obtained from the computed data of the farm. Predicted Lactation yield (305 days) was calculated by using ratio estimates of partial lactation of Murrah buffaloes (Thomas and Sastry, 1991). The lactation yield up to 12 weeks was multiplied by the corresponding ratio estimates of 2.8096 to obtain estimates of lactation yield. 


\section{Milk components}

The milk components, including fat, protein, lactose, total solids and Solid Not Fat (SNF) was measured from calving to 12 weeks postpartum at weekly intervals. The representative milk samples were collected from the milking bucket after complete milking of the individual animal. The milk samples were analyzed by auto analyzer (Ultrasonic auto milk analyzer, Netco Pvt. Ltd.)

\section{Reproductive parameters}

Post-Partum estrus was observed by the acceptance of a male by the female, which is the most prominent and reliable symptoms of estrus in buffalo. The service period was calculated from the date of calving to date of successful service leading to conception. The first service conception rate was calculated by the percentage of experimental buffaloes conceiving out of the total buffaloes at first insemination. Numbers of service per conception were obtained from the record of the farm.

\section{Statistical analysis}

The data obtained in the study was statistically analyzed using ANOVA described by Snedcor and Cochran (1994) to study the impact of BCS on performance of Murrah buffaloes.

Mathematical model:

$Y_{i j}=\mu+B_{j}+e_{i j}$

Yij $=$ Observation under the $i^{\text {th }}$ group

$\mu=$ Overall mean

$B_{j}=$ Fixed effect of $i^{\text {th }}$ group $(i=1,2,3,4 \& 5)$

$e_{i j}=$ Random error, which is assumed to be normally and independently distributed with zero mean and constant variance $\sigma^{2} \mathrm{e}$
Means showing significant differences in the ANOVA table were compared using the Duncan Multiple Range Test (Steel and Torrie, 1980).

\section{Results and Discussion}

\section{Body Condition Score (BCS)}

The fortnightly changes in BCS pattern after calving to 90 days post-partum in Murrah buffaloes are presented in table 1 and figure 1 . The result of the present study indicated that there was decrease in BCS after calving in all the groups. In G1 group BCS loss started from $15^{\text {th }}$ day post-partum and continued up to $30^{\text {th }}$ day which was found to be significant $(\mathrm{P}<0.05)$. After that $\mathrm{BCS}$ increased gradually and reached to its pre-partum level at $90^{\text {th }}$ day post-partum. Loss of BCS in G2 and G3 groups, continued upto $90^{\text {th }}$ day post-partum which was found to be significant $(\mathrm{P}<0.05)$.

The highest loss of BCS was observed in animals of G3 group during study period.

\section{Milk yield}

The changes in average fortnightly milk yield (with different BCS groups in Murrah buffaloes are presented in table 2 and figure 2. In G1 group animals, the average fortnight milk yield increased up to $60^{\text {th }}$ day and thereafter declined up to $90^{\text {th }}$ day, which was non-significant. In $\mathrm{G} 2$ group animals, the average fortnight milk yield increased up to $60^{\text {th }}$ day, remained same up to $75^{\text {th }}$ day and thereafter declined up to $90^{\text {th }}$ day, which was non-significant. In G3 group animals, the average fortnight milk yield increased up to $45^{\text {th }}$ day, remained same up to $60^{\text {th }}$ day and thereafter declined up to $90^{\text {th }}$ day, which was also found to be non-significant. G3 group animals produced highest total milk than G1 and G2 group animals, however the difference was not significant (Table 3). 
Fig.1 Changes in BCS from calving (pre-partum) to 90 days postpartum in different groups of Murrah buffaloes

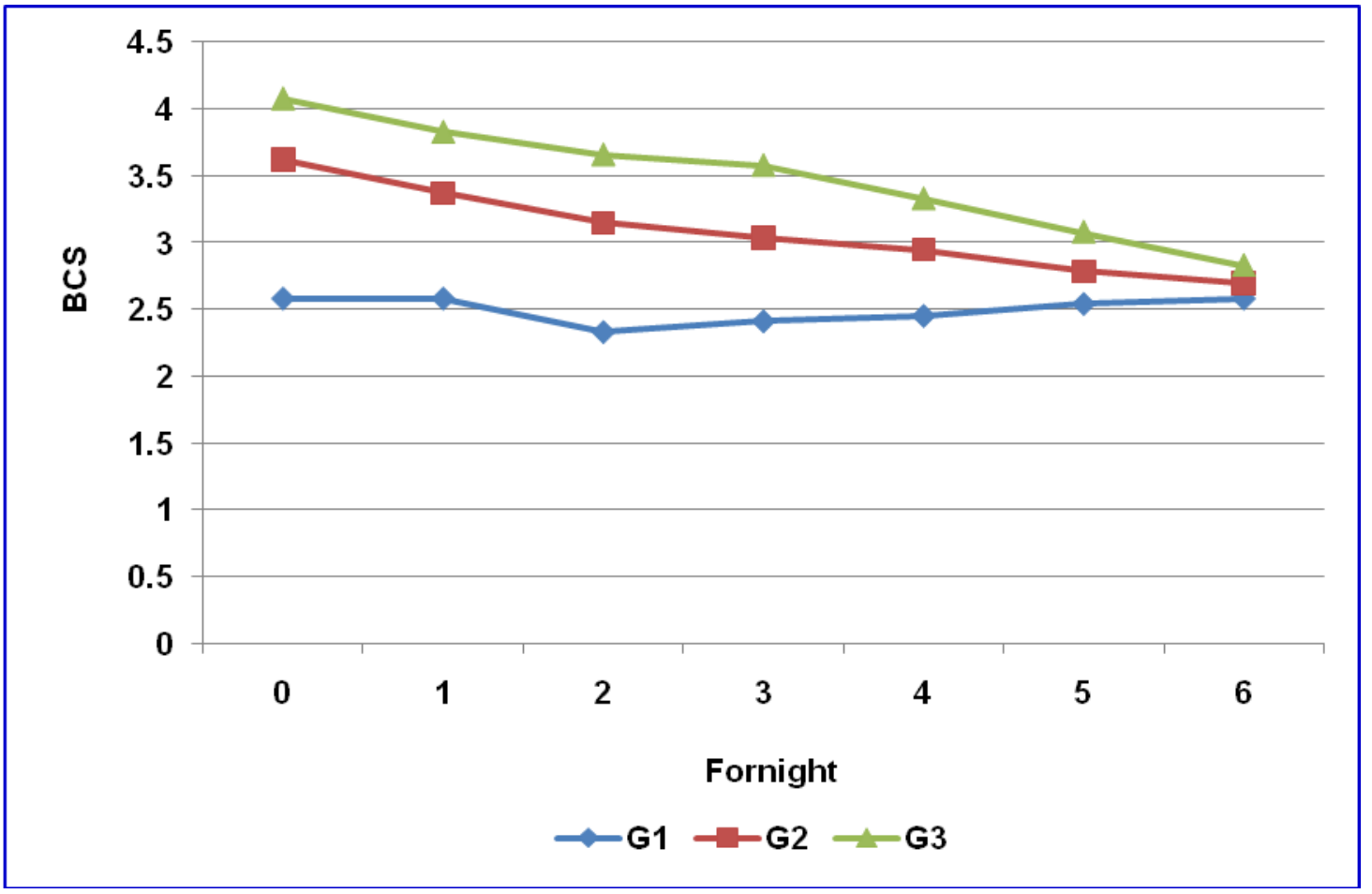

Fig.2 Average fortnightly milk yield (litre) with different BCS groups in Murrah buffaloes

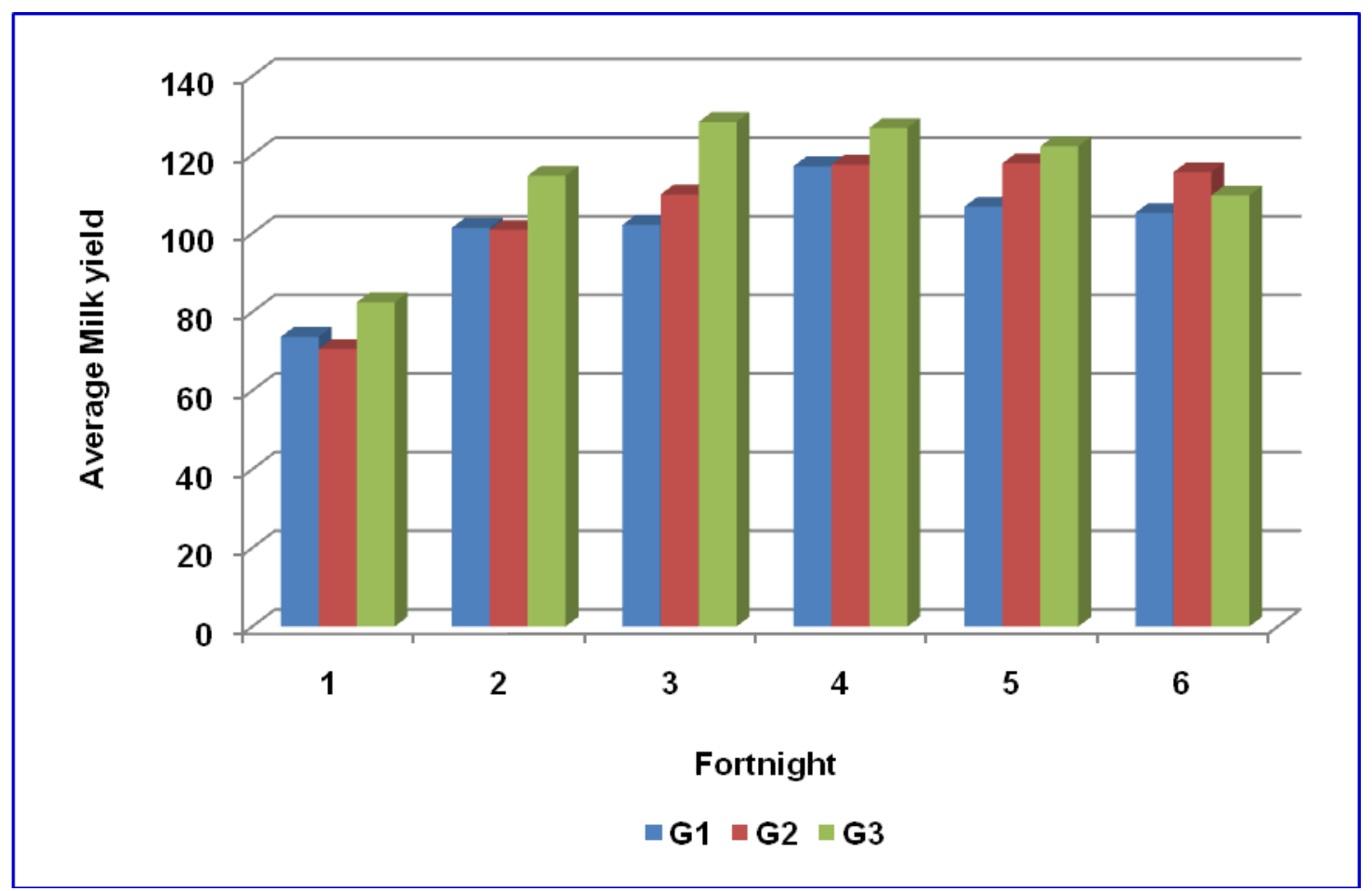


Grouping of animals

\begin{tabular}{|c|c|c|}
\hline Groups & No. of animals & BCS \\
\hline G1 & 06 & $2.50-3.00$ \\
\hline G2 & 06 & $3.25-3.75$ \\
\hline G3 & 06 & 4.00 and above \\
\hline
\end{tabular}

Table.1 Changes in BCS from calving (pre-partum) to 90 days postpartum in Murrah buffaloes

\begin{tabular}{|c|c|c|c|}
\hline $\begin{array}{c}\text { Fortnight } \\
\text { Intervals days }\end{array}$ & G1 & BCS groups & \\
\hline At calving & $2.58^{\text {ap }} \pm 0.08$ & G2 & G3 \\
\hline $\mathbf{1 5}$ & $2.58^{\text {apq }} \pm 0.08$ & $3.62^{\text {bp }} \pm 0.06$ & $4.08^{\text {bp }} \pm 0.06$ \\
\hline $\mathbf{3 0}$ & $2.33^{\text {aqr }} \pm 0.08$ & $3.37^{\text {bqq }} \pm 0.06$ & $3.83^{\text {bq }} \pm 0.06$ \\
\hline $\mathbf{4 5}$ & $2.41^{\text {aqr }} \pm 0.05$ & $3.15^{\text {bqr }} \pm 0.10$ & $3.66^{\text {bqr }} \pm 0.12$ \\
\hline $\mathbf{6 0}$ & $2.45^{\text {ast }} \pm 0.08$ & $3.04^{\text {brs }} \pm 0.08$ & $3.58^{\text {br }} \pm 0.06$ \\
\hline $\mathbf{7 5}$ & $2.54^{\mathrm{a}} \pm 0.12$ & $2.95^{\text {brst }} \pm 0.10$ & $3.33^{\text {bs }} \pm 0.06$ \\
\hline $\mathbf{9 0}$ & $2.58^{\text {ap }} \pm 0.11$ & $2.79^{\text {bst }} \pm 0.11$ & $3.08^{\text {bt }} \pm 0.06$ \\
\hline
\end{tabular}

${ }^{a, b}$ Means within a row with different superscripts differ significantly $(\mathrm{P}<0.01)$ and

$\mathrm{p}, \mathrm{q}, \mathrm{r}, \mathrm{s}, \mathrm{t}, \mathrm{u}$ Means within a column with different superscripts differ significantly $(\mathrm{P}<0.05)$

Table.2 Average fortnightly milk yield (litres) in different BCS groups in Murrah buffaloes

\begin{tabular}{|c|c|c|c|}
\hline \multirow{2}{*}{$\begin{array}{c}\text { Fortnight } \\
\text { Intervals (days) }\end{array}$} & \multicolumn{3}{|c|}{ Average Milk yield of animals in BCS groups (lit.) } \\
\hline $\mathbf{1 5}$ & $\mathbf{G 1}$ & $\mathbf{G 2}$ & G3 \\
\hline $\mathbf{3 0}$ & $71.67^{\mathrm{p}} \pm 5.00$ & $76.70^{\mathrm{p}} \pm 3.85$ & $83.80^{\mathrm{p}} \pm 8.15$ \\
\hline $\mathbf{4 5}$ & $101.42^{\mathrm{q}} \pm 4.64$ & $103.40^{\mathrm{q}} \pm 7.14$ & $110.10^{\mathrm{pq}} \pm 15.67$ \\
\hline $\mathbf{6 0}$ & $102.25^{\mathrm{q}} \pm 7.84$ & $108.70^{\mathrm{q}} \pm 6.68$ & $124.60^{\mathrm{q}} \pm 6065$ \\
\hline $\mathbf{7 5}$ & $117.08^{\mathrm{q}} \pm 4.90$ & $114.10^{\mathrm{q}} \pm 10.92$ & $124.14^{\mathrm{q}} \pm 4.35$ \\
\hline $\mathbf{9 0}$ & $106.75^{\mathrm{q}} \pm 7.09$ & $114.30^{\mathrm{q}} \pm 9.02$ & $118.40^{\mathrm{q}} \pm 5.96$ \\
\hline
\end{tabular}

${ }^{\mathrm{p}, \mathrm{q}}$ Means within a column with different superscripts differ significantly $(\mathrm{P}<0.05)$

Table.3 Effect of BCS on production performance in Murrah buffaloes

\begin{tabular}{|l|c|c|c|}
\hline & G1 & G2 & G3 \\
\hline Total milk yeild in litres (90 days) & $604.33 \pm 16.94$ & $628.20 \pm 40.53$ & $667.10 \pm 48.71$ \\
\hline Predicted lactation milk yeild (305 days) (litres) & 1694.36 & 1793.48 & 1941.55 \\
\hline Days to attain peak milk yeild (litres) & 54.50 & 42.40 & 38.36 \\
\hline Milk Fat percentage & $6.56 \pm 0.09^{\mathrm{a}}$ & $6.79 \pm 0.95^{\mathrm{b}}$ & $7.19 \pm 0.06^{\mathrm{c}}$ \\
\hline Milk Solid Not Fat percentage & $8.73 \pm 0.06$ & $9.25 \pm 0.64$ & $9.95 \pm 0.08$ \\
\hline Milk protein percentage & $3.37^{\mathrm{a}} \pm 0.03$ & $3.58^{\mathrm{a}} \pm 0.04$ & $3.94^{\mathrm{b}} \pm 0.03$ \\
\hline Milk lactose percentage & $4.44 \pm 0.05^{\mathrm{a}}$ & $4.73 \pm 0.05^{\mathrm{b}}$ & $5.12 \pm 0.04^{\mathrm{c}}$ \\
\hline Milk total solids percentage $^{\mathrm{a}, \mathrm{b}, \mathrm{c}}$ Means within a row with different superscripts differ significantly $(\mathrm{P}<0.05)$ & $15.30 \pm 0.11^{\mathrm{a}}$ & $16.03 \pm 0.13^{\mathrm{b}}$ & $17.12 \pm 0.08^{\mathrm{c}}$ \\
\hline
\end{tabular}


Table.4 Effect of BCS on reproductive traits in Murrah buffaloes

\begin{tabular}{|l|c|c|c|}
\hline & G1 & G2 & G3 \\
\hline Post-partum estrus (days) & $63.64^{\mathrm{a}} \pm 5.63$ & $39.46^{\mathrm{b}} \pm 5.46$ & $52.8^{\mathrm{c}} \pm 4.25$ \\
\hline No. of service per conception & $2.8^{\mathrm{a}} \pm 0.59$ & $1.68^{\mathrm{b}} \pm 0.36$ & $1.90^{\mathrm{c}} \pm 0.50$ \\
\hline 1st service conception rate (\%) & 28.50 & 62.65 & 48.56 \\
\hline Service period (days) & $113.5^{\mathrm{a}} \pm 15.42$ & $69.88^{\mathrm{b}} \pm 12.46$ & $82.48^{\mathrm{c}} \pm 5.83$ \\
\hline
\end{tabular}

The G3 group animals attained their peak yield earlier compared to $\mathrm{G} 2$ and $\mathrm{G} 1$ group of animals (Table 3).

The result of the study indicated that highest predicted lactation milk yield was obtained in G3 group animals and the lowest predicted lactation milk yield was obtained in G1 group animals. There was no significant difference between the G1, G2 and G3 groups.

\section{Milk composition}

The average fat percentage significantly $(\mathrm{P}<0.05)$ differed between the three groups throughout the study period. The G3 group animals had the highest fat percentage in the milk followed by G2 and G1 group animals (Table 3).

There was no significant difference in fortnight average Solid Not Fat (SNF) percentage between the three groups throughout the study period. G3 group animals had highest SNF percentage among all the groups (Table 3 ).

The G3 group of animal had significant $(\mathrm{P}<0.05)$ difference in milk protein percentage with $\mathrm{G} 1$ and $\mathrm{G} 2$ groups animal, but there was no significant difference between G1 and G2 group. G3 group had highest milk protein percentage followed by $\mathrm{G} 2$ and $\mathrm{G} 1$ groups (Table 3).

The milk lactose percentage significantly $(\mathrm{P}<0.05)$ differed between the three groups throughout the study period. The G3 group animals had the highest milk lactose percentage in the milk followed by G2 and G1 group animals (Table 3 ).

There was significant $(\mathrm{P}<0.01)$ difference in Total Solid (TS) percentage in the milk of G1, G2 and G3 groups throughout the study period. The average TS percentage in G3 group animals were highest followed by in G2 and G1 group (Table 3).

\section{Reproductive performance}

The animals of G2 group had shorter postpartum estrus period, fewer services per conception, higher first service conception rate and shorter service period than G1 and G3 group (Table 4).

The changes in BCS pattern in the present study were in agreement with that of Banuvalli et al., (2014) who in crossbred dairy cows reported that highest loss of BCS was seen in cows with calving BCS $>3.50$. The dairy cow with high genetic merit, have a higher predisposition for mobilization of body fat reserves to cover milk production demands (Pryce et al., 2000). Similarly, Horan et al., (2005) reported that BCS changes in high producing animals after calving were higher than in animals with lower genetic merit.

The results of present study were in agreement with Dechow et al., (2002) who reported higher milk yields in cows with high BCS losses. The results were also in 
agreement with Berry et al., (2003) who reported that animals selected for higher milk yield mobilized her lipid reserves more than low producers. Thus, compromise on her body condition is more in high producers than lower ones. The results were also in agreement with Samarütel et al., (2006) who reported that, thin cows at the calving could not achieve their genetic milk yield potentials due to lack of body reserves that would support increasing the milk yield at the beginning of lactation. The present findings were also similar to that of Roche et al., (2007a) who reported that lower calving BCS is associated with reduced production. Two presumptions were suggested regarding this positive relation: first is the increase in the mammary cells of the cows with high condition scores during the calving period and the second suggestion is the reduction in the decomposition of foods. Contrary to this study, Anitha et al., (2011) reported that buffaloes of BCS group 3.5-3.99 had higher ( $\mathrm{P}<0.01)$ milk yields up to 18 weeks of lactation $(\mathrm{kg}), 305$ day predicted lactation yield $(\mathrm{kg})$, and peak milk yield $(\mathrm{kg})$ followed by buffaloes of BCS group 4.0-4.49. The study was also in disagreement with Bayram et al., (2012) who reported that actual milk yield and 305 day milk yield of thin cows were significantly higher than those of the moderate cows $(\mathrm{P}<0.01)$.

The study revealed that BCS had significant $(\mathrm{P}<0.01)$ effect on the reproductive traits under the study. These findings were in agreement with the reports of Buckley et al., (2003), Sarjan and Anitha (2013). Extended service period and increased number of services per conception were also reported in cows with low BCS at calving due to late postpartum ovulation or excessive inactive ovum (Lopez-Gatius et al., 2003; Roche et al., 2007b). Tapk1 et al., (2005) reported significant differences between the service period (78 and 94 days) and number of services per conception (1.27 and 1.53) in the fat $(\leq 4)$ and over fat $(>4)$ groups during the dry period. Bayram et al., (2012) reported that the service period of the cows with low condition score at calving was significantly longer and their number of services per conception was significantly lower than moderate group. As the nutrients obtained through the ration is insufficient for lactation during the first 60-90-day period of lactation, body reserves are used to attempt to meet the necessary energy requirement. In case of condition loss as a result of negative energy balance, LH hormone level in the animal decreases and the response to $\mathrm{LH}$ reduces to a low level. As a result, there is a decrease in the available follicle number and thus in the number of ovule and follicle (Butler, 2000). Since the low BCS derived from the negative energy balance during the early lactation period resulted in low LH release and weak follicle formation, it causes extended postpartum estrus cycle and extended service period (Jilek et al., 2008). Dechow et al., (2002) found a genetic correlation between the condition loss and service period ranging from 0.29 to 0.68. According to this relationship, service period extends with the increase in BCS loss.

Thus in the present study, it was observed that BCS subsequently related to the production and fertility status of an animal. Thus, BCS may be used as a tool to aid in the management of nutritional and production programs in dairy herds. However, additional long term studies are required with more number of animals observing the impact of $\mathrm{BCS}$ to test the marginal condition effect.

\section{References}

Anitha, A., Sarjan Rao, K., Suresh, J., Srinivasa Moorthy, P.R. and Kotilinga Reddy, Y. 2011.A Body Condition Score (BCS) system in Murrah Buffaloes, 30 (1): 7999. 
Banuvalli, N., Bhaskaran, R., Krishnamurthy, U., Gurraj, P. M., Kumar, H. and Ramesh, H. S. 2014. Effect of Body Condition Score at parturition on post-partum productive and reproductive performance in cross breed dairy Cows. International Journal of Livestock Research. 4(8): 5-11.

Bayram, B., Aksakal, V. and Akbulut, Ö. 2012. Effect of the Body Condition Score on some reproduction and milk yield traits of Swedish Red and White Cows. The Journal of Animal and Plant Sciences. 22(3): 545-551.

Berry D. P., Buckley, F. and Dillon, P. 2007. Body condition score and live-weight effects on milk production in Irish Holstein-Friesian dairy cows. Animal. 1(9): 1351-1359.

Berry, D.P., Buckley, F., Dillon, P., Evens, R.D., Rath, M. and Verkamp, R.F. 2003. Genetic relationships among body condition score, body weight, milk yield and fertility in dairy cows. Journal of Dairy Science. 86: 2193-2204.

Buckley, F., O'Sullivan, K., Mee, J.F., Evans, R.D. and Dillon, P. 2003. Relationship among milk yield, Body condition, cow weight, and reproduction in spring-calved Holstein-Friesians. Journal of Dairy Science. 86: 2308-2319.

Butler, W. R., 2000. Nutritional interactions with reproductive performance in dairy cattle. Animal Reproduction Science. 60: 449-457.

Dechow C. D., Rogers, G. W. and Clayt, J. S. 2002. Heratibility and correlations among body condition score loss, body condition score, production and reproductive performance. Journal of Dairy Science. 85, 3062-3070.

Gransworthy, P.C. 1988. The effect of energy reserves at calving on performance of dairy cows. In: P.C. Gransworthy (eds), Nutrition and Lactation in the Dairy Cow, $1^{\text {st }}$ ed., Butterworths, London, UK, 157170.

Horan, B., Dillon, P., Faverdin, P., Delaby, L., Buckley, F. and Rath, M. 2005. The interaction of strain of Holstein- Friesian cows and pasture-based feed systems on milk yield, body weight, and body condition score. Journal of Dairy Science. 88: $1231-1243$.

Janus, E. and Borkowska, D. 2012.Changes of body condition of cows, daily milk yield and its composition during the course of lactation. Acta Scientiarum Polonorum Zootechnica. 1(1): 75-84.

Jeffrey, K. R. and James, G. L. 1989. Body condition scoring to predict feeding program problems for dairy cattle, Dairy Update, Department of Animal Science, University of Minnesota, St. Paul.

Jilek, F., Pytloun, P., Kubesova, M., Stipkova, M., Bouska, J., Volek J., Frelich, J. and Raymon, R. 2008. Relationships among body condition score, milk yield and reproduction in Czech Fleckvieh cows. Czech Journal of Animal Science. 53 (9): 357-367.

Lents, C.A., White, F, J., Ciccioli, N.H., Wettemann, R.P., Spicer, L.J. and Lalman, D.L. 2008. Effects of body condition score at parturition and postpartum protein supplementation on estrous behavior and size of the dominant follicle in beef cows. Journal of Animal Science. 86(10): 2549-56.

Lopez-Gatius, F., Yaniz, J. and Madriles-Helm, D. 2003. Effects of body condition score change on the reproductive performance of dairy cows: A meta-analysis. Theriogenology. 59: 801-812.

Mushtaq, A. 2010. Effect of Physiological states on milk fatty acids profile in dairy cows and buffaloes. Ph.D. Thesis, Livestock production and management, North-West Frontier Province, Agricultural University, Peshawar.

Nielsen, B. L. 1999. Perceived welfare issues in dairy cattle with special emphasis on metabolic stress. In: Oldham, J. D., G. Simm, A. F. Groen, B. L. Nielsen, J. E. Pryce, and T.L.J. Lawrence (eds), Metabolic Stress in Dairy Cows, British Society of Animal Science, Occasional Publication, 24, 1-8. 
Peters, A.R. and Ball, P.J. 1988. Reproduction in Cattle, $1^{\text {st }}$ Edn. Butter Worth and Co. Ltd., London, UK.

Pryce J. E., and Løvendahl, P. 1999. Options to reduce vulnerability to metabolic stress by genetic selection. In: J. D. Oldham, G. Simm, A. F. Groen, B. L. Nielsen, J. E. Pryce, and T.L.J. Lawrence (eds), Metabolic Stress in Dairy Cows, The British Society of Animal Science, Occasional Publication, 24, 119-128.

Pryce, J.E., Coffey, M.P. and Brotherstone, S. 2000. The genetic relationship between calving interval, body condition score and linear type and management traits in registered Holsteins. Journal of Dairy Science. 83(11): 2664-2671.

Roche, J.R., Lee, J.M., Macdonald, K.A. and Berry, D.P. 2007b. Relationships among body condition score, body weight and milk production variables in pasturebased dairy cows. Journal of Dairy Science. 90 (8): 3802-3815.

Roche, J.R., Macdonald, K.M., Burke, C.R., Lee, J.M. and Berry, D.P. 2007a. Associations between body condition score, body weight and reproductive performance in seasonal-calving pasturebased dairy cattle. Journal of Dairy Science. 90(1): 376-391.

Samarütel, J., Ling, K., Jaakson, H., Kaart, T. and Kart, O. 2006. Effect of body condition score at parturation on the production performance, fertility and culling in primiparous Estonian Holstein cows. Veterinarija ir Zootechnika. 36 (58): 69-74.

Sarjan Rao, K. and Anitha, A. 2013. Body Condition Score (BCS) system in Murrah buffaloes. Buffalo Bulletin. 32 (Special Issue 2): 1290-1298.

Singh, R.R., Dutt, T., Joshi, H.C., Sinha, R.R.K. and Singh, M., 2009. Effect of body condition score on performance traits in crossbred dairy cows. Journal of Applied Animal Research. 36: 283-286.

Singh, V., Singh, V.K., Singh, S.P. and Sahoo, B. 2015. The effect of body score condition at calving on milk yield, milk composition and udder health status of dairy animals. Journal of Dairy, Veterinary and Animal Research. 2(2): 22-26.

Snedecor, G.W. and Cochran, W.G. 1994. Statistical Methods, 7th Edn., Oxford and IBH Publishing Co., New Delhi.

Steel, R.G.D. and Torrie, J.H. 1980. Principles and procedures of statistics- A biometrical approach. $2^{\text {nd }}$ Edn., McGraw Hill Book Co., New York, NY, USA.

Tapk1, İ., Önal, A. G. and Ünalan A. 2005. Effects of body condition score on calf birth weight, reproductive traits, milk yield and composition of Holstein Friesain cows during the dry period 2 . Calf birth weight and reproductive traits (In Turkish), MKU Ziraat Fakültesi Derg. 10 (1-2): 47-54.

Thomas, C.K. and N.S.R. Sastry. 1991. Dairy Bovine Production, Kalyani Publishers, New Delhi, India.

Treacher, R.J., Reid, I.M. and Roberts, C.J. 1996. Effect of body condition at calving on the health and performance of dairy cows. Animal Production. 43: 1-6.

\section{How to cite this article:}

Patel, M., G.P. Lakhani, S. Ghosh, S. Nayak, B. Roy, R.P.S. Baghel and Jain, A. 2018. Effect of Body Condition Score on Milk Production, Milk Composition and Reproductive Performance of Lactating Murrah Buffaloes. Int.J.Curr.Microbiol.App.Sci. 7(11): 1204-1212. doi: https://doi.org/10.20546/ijcmas.2018.711.140 